has received by gift from $\mathrm{Mr}$. S. R. Mitchell crystals and platy aggregates of the hydrous magnesium phosphate, newberyite, from the guano deposits of the Skipton Caves, near Ballarat, Victoria, and from Capt. R. S. Pain a fine collection of doubly terminated quartz crystals, variously coloured, from a gypsum hill in the Salt Range, Punjab. Asbestos has been presented by Mr. L. G. Brandon-Fleming from India, and by the Griqualand Exploration and Finance Co. from its mines in Griqualand West. Lady Kleinwort has given a fine stalactite from the Mammoth Caves in Kentucky. The purchases include a magnificent group of crystals of tarnowitzite, the variety of aragonite containing lead carbonate, from Tsumeb in South-West Africa, and a large group and a large twin plate of selenite, the crystallised form of gypsum.

\section{Imperial Forestry Institute, Oxford}

THE Imperial Forestry Institute was established in 1924 at Oxford and placed under the direction of the professor of forestry-the School of Forestry and the Institute being kept separate. In the eleventh annual report (Hollywell Press, Oxford, 1935) it is announced that, owing to the work of the Institute having greatly increased, a new appointment of director of the Institute alone has been made, the Oxford professor of forestry remaining as general head of the Department and to remain in general administrative charge of the School and the Institute. Mr. J. N. Oliphant, deputy director of forestry, Malaya, has been appointed to the new post. It is stated in the report that "With a revival of recruitment for the forest services the number [of students at the Institute] may be expected to approach the normal once more". Among the research work undertaken is the investigation into the cricket-bat willow. It is to be hoped that something definite and practical may come out of this work to assist landowners in Great Britain possessing areas eminently suited to the growth of the willow. The report mentions an estate where five hundred specimens of a well-known hybrid were supplied fifteen years ago; it being discovered years afterwards that they were not the true Salix ccerulea. The present writer knows of a case, now twenty-five years old, where a much larger number of a so-called cricket-bat willow were planted with a considerable financial loss to the estate. The owner wants a practical remedy. Another investigation is with the elm. The report says : "The elm studies begun by Dr. Bancroft in 1933 have been continued in the Cotentin region of Lower Normandy, the south of England, the east of Scotland, and in S.W. Ireland; the later investigations have been concerned more particularly with the origin of the English elm, Ulmus campestris, and of the Guernsey elm, Ulmus stricta var. sarniensis. Interesting observations were made in the Cotentin in July 1935, concerning the connexion between habit-type and climatic conditions, the effect of growth-conditions on the quality of the timber, and the effect of the introduction of Ulmus montana Stokes in the neighbourhood of Bricquebec."

\section{Inexhaustibility of Oil Resources in America}

Scrence Service of Washington, D.C., reports that Mr. A. J. Byles, president of the American Petroleum Institute, assured members at their sixteenth annual meeting that exhaustion of American petroleum and products was beyond the limits of man's powers of prediction. During the last decade, a number of facts pointing to their inexhaustibility have come to light. Proved reserves are now estimated at twice the amount they were in 1925 , in spite of the volume of oil withdrawn. Oil has been found at greater depths, and in some cases even below old pools ; moreover, there still remain unexplored more than a billion acres of geological formations which may prove to be oil-bearing. Deposits of bituminous coal are to all intents and purposes unlimited, and these can be drawn upon if necessary to meet the demand for motor fuel. Further, more than a hundred billion barrels of oil are said to be obtainable from shale oil deposits. Improved scientific methods of discovery and production have facilitated greater recovery of oil per well and more economical usage of oil. $\mathrm{Mr}$. Byles expressed the view that rumours of oil scarcity were spread merely in order to frighten people into advocation of federal control of the industry.

\section{Pollen Grains}

Miss AnNie D. Betrs, editor of The Bee World, writing with reference to the reviewer's comment on the "lack of comprehensive works" in discussing Wodehouse's "Pollen Grains" (Nature, Feb. 22, p. 294), has directed our attention to two recent works dealing with pollen, which, though primarily designed for the purpose of identifying pollen grains in honey, may be of use in other spheres of pollen study. These works are: Armbruster, "Pollenformen und Honigherkunftsbestimmung" (1929, and a supplement 1935); Zander, "Pollengestaltung und Herkunftsbestimmung bei Blütenhonig". The firstmentioned publication contains drawings of the pollen of more than 1,200 species of plants; the second has photographs of more than 700 species.

\section{Dovedale}

The Pilgrim Trust has just presented important areas on both banks of the Dove to the National Trust. The Bostern Estate of 415 acres has been acquired from Lord Daresbury, and of this about 165 acres of the Derbyshire slopes of Dovedale will become the property of the Trust. The estate is in the heart of Dovedale and includes Bayley Hill and Bostern Nab-both over 1,000 ft., with views extending to Kinder Scout, Axe Edge moors and Chelmorton Low to the north, and the hills of Staffordshire and south Derbyshire to the south. The other area acquired through the generosity of the Pilgrim Trust lies on the Staffordshire bank farther north and comprises the Alstonefield Glebe land of 70 acres with a long frontage to the Dove and the more austere beauties of upper Dovedale. It is opposite Biggin Dale and the Iron Tors presented by Mr. R. MeDougall and Mr. Kerfoot. The new property adjoins Wolfscote Dale and includes Peasland Rocks 